Historic, Archive Document

Do not assume content reflects current scientific knowledge, policies, or practices. 



\section{A NEW PRUNE}

\section{THE STANDARD}

To Raise by the Carload in Warm Climates and to Sell Everywhere

A NEW EARLY CHERRY S L

THE BURBANK CPAI RARY,

A GOOD LITTLE HARDY PLUM/ash

\section{THE GLOW}

For Home Use by Those Who Like Extra Good Things,

and for Cold Climates

A NEW STRAWBERRY

THE PATAGONIA

Also Some Other Matters of More or Less Interest

to Fruit Growers Everywhere, and

HOW TO JUDGE NOVELTIES

\section{LUTHER BURBANK}




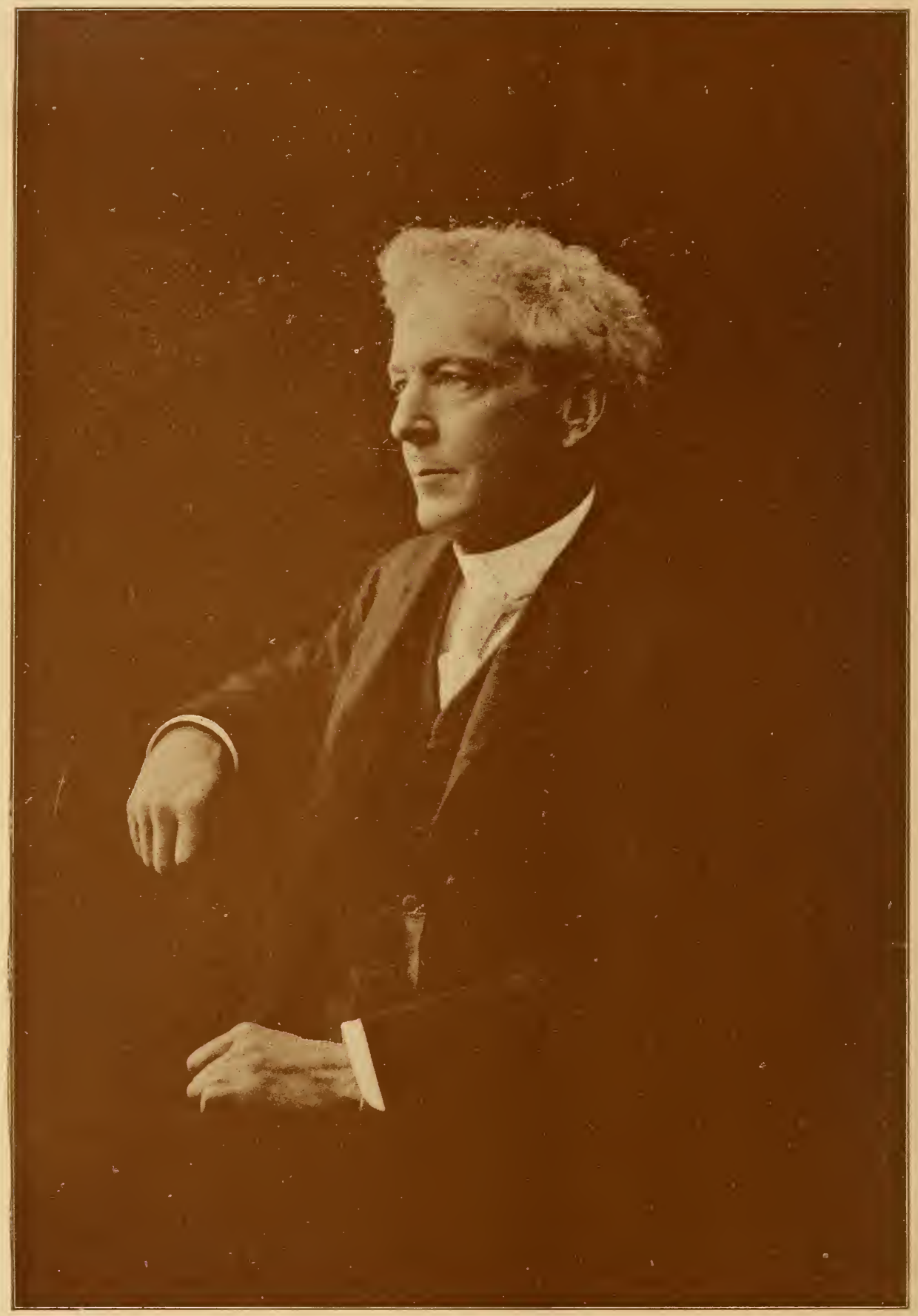

In all Europe there is no one who can even compare with Luther Burbank. A true worker must ever pay the price of genius.-Prof. Hugo De Vries, University of Amsterdam, Amsterdam, Holland. 


\section{How to Judge Novelties}

The ripe fruit is clropped at last without violence, but the lightning fell and the storm raged, and strata were deposited and uptorn and bent back, and Chaos moved from beneath, to create and flavor the fruit on your table to-day."

Emerson.

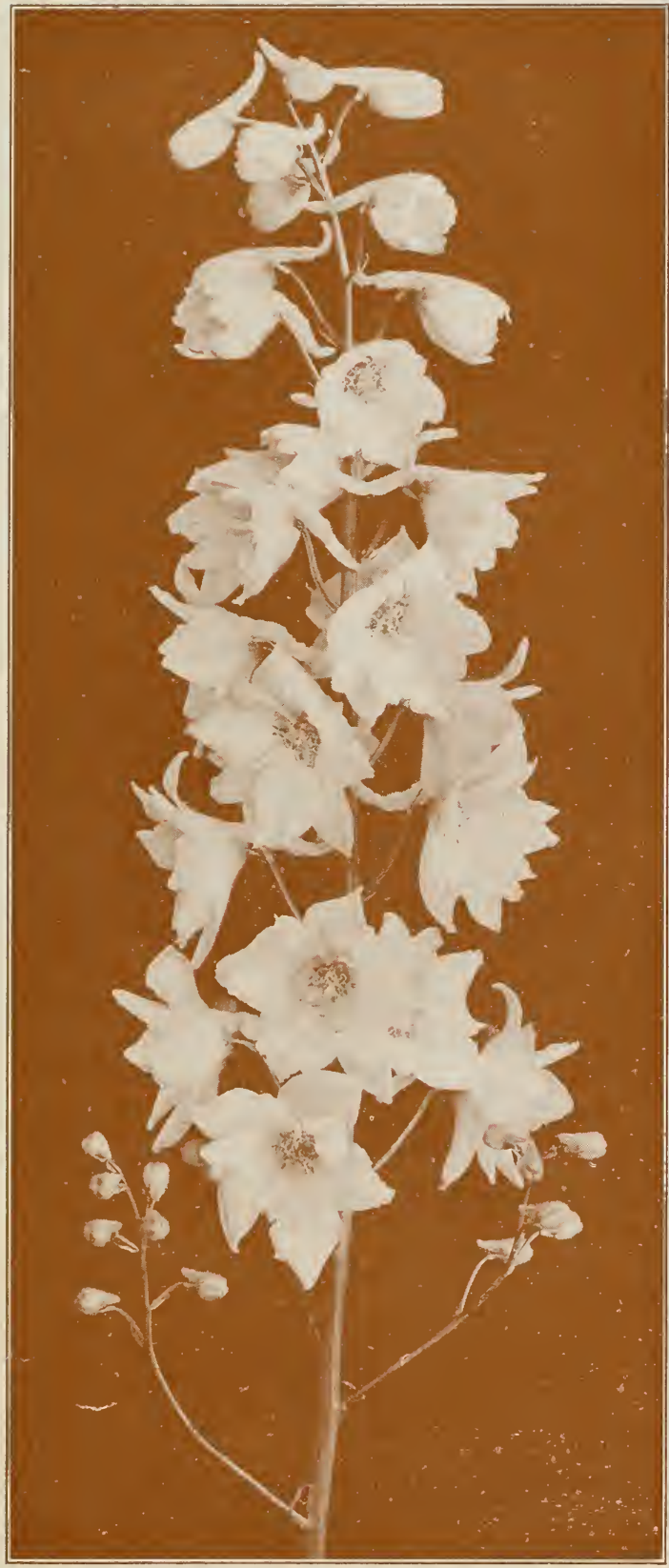

The Improved Larkspur.
It is very rare that a fruit variety of any kind will thrive under all conditions of soil, climate and locality. No fruit thrives equally well in all parts of the United States even. Two or three of the ancient European and early. American standards approach this cosmopolitan tendency. The old Bartlett pear thrives fairly perhaps in half the States of the Union, the Ben Davis and the Rhode Island Greening apples thrive over a large territory, perhaps including nearly one-third the United States, though their usefulness as standard varieties is very much more limited.

Among the older plums the Wild Goose type, though not of superior quality, thrives widely. Among peaches, the types which thrive best in the South and West are generally worthless in the Northern States. The same state of affairs exists with grapes, apricots, almonds, oranges, lemons, olives, figs, prunes and cherries, strawberries and other berries. The old hardy Concord grape thrives as generally as any among grapes, but the territory on which it is grown as a standard variety is quite limited.

When we extend cur study of fruits from a narrow local point to a more comprehensive view of the whole subject, it is at once seen that success in the produc- 
tion of fruit depends upon the most delicate adjustments of soil and climate and locality, and that certain varieties which are a success in one locality may be, and often are, a complete failure a few miles distant, or nearby on a different soil or at a different elevation.

NO ONE VARIETY OF FRUIT CAN BE GROWN EVERYWHERE. THIS FACT SEEMS TOO PLAIN EVEN TO BE MENTIONED.

From having made a life study of these conditions, and having produced several millions of new fruits, using in this constructive architectural work nearly or quite four hundred species and tens of thousands of varieties, all in the constant effort to eliminate faults and substitute virtues, these observations have been most deeply impressed, and all intelligent, progressive fruit growers are now aware of some of the benefits conferred by this enormously expensive work, a work such as no man or body of men, community or even government has ever undertaken, much less carried to a successful issue.

Nearly two hundred and forty thousand dollars of my own private earnings in other lines have been used in this work, not one-tenth of which has ever been received in return, nor was it expected, as few originators of new plants have ever made it pay themselves no matter how many untold millions their work may have been of benefit to others. No patent can be obtained on any improvement of plants, and for one I am glad that it is so. The reward is in the joy of having done good work, and the impotent envy and jealousy of those who know nothing of the labor and sacrifices necessary, and who are by nature and cultivation, kickers rather than lifters.

Happening however to be endowed with a fair business capacity I have so far never been stranded as have most others who have attempted similar work, even on an almost infinitely smaller scale.

It takes nearly as long and is far more difficult to adapt the average grower of fruits to the priceless qualities, characters and values of a new and unique fruit than to adapt a new fruit to the real wants of the grower. These facts have both a ludicrous and a pathetic interest; it must necessarily take four or five years to fairly test new fruits in a warm climate, and sometimes ten in a more inhospitable one, and where fruits are not as well known and extensively grown.

The BURBANK PLUM when first introduced was, by dealers and shippers, canners and dryers, generally pronounced as "not like other plums," and they would have none of it ; but although generally introduced less than twenty years ago it is perhaps to-day more widely known, more thoroughly cosmopolitan, and more generally grown than any other plum of any name or kind produced either by nature or by the scientific experiments of man since the dawn of history; growing both where other plums can and where they cannot be grown, thriving well in Canada or Brazil, Japan or Africa, Borneo or Argentina, Russia or New Zealand. Hundreds of better plums 
have since been produced on my experiment farms and two of these are described in this circular, and more will be offered later.

The BURBANK CRIMSON IVINTER RHUBARB met with flat failure in interesting anybody, simply because it had absolutely new and unique qualities which at first were wholly mappreciated. To-day nearly all rhubarb growers in warm climates recognize it as the best and most profitable of all rhubarbs, and it is without doubt the most valuable vegetable introduced during the last quarter of a century. Fortunes have been made and are still being made from it in California and also in Florida. It has been rightly named "The Mortgage Lifter." Chief Forester of the English Government for Africa reports that at Cape Town, where all other rhubarbs had been a complete failure for two hundred years, the BURBANK CRIMSON IVINTER is a complete success, as it has later proved to be throughout all of Africa; where it is being generally introduced by the government officials. BURBANK'S GIANT is a great improvement over all others, excelling the original Crimson Winter Rhubarb at least four hundred per cent. This is becoming even more popular, if possible. It will produce stalks of most delicious flavor throughout the whole year, outyielding any of the older rhubarbs at least three to one. Other greatly improved new ones are now also offered.*

The BURBANK POTATO, which was produced on my old home place in Massachusetts in 1873-nearly forty years ago-received little attention at first, but to-day is grown each season by the million bushels. Many hundreds of new varieties of potatoes have been introduced since, but the BURBANK is more and more extensively grown as a main crop. One of the best known horticulturists of America agrees with others, that the BURBANK is of late gradually but surely taking the lead of all other varieties in Iowa, Michigan, Wisconsin, Utah, Missouri, and in the States of Oregon and Washington it is now the universal standard, and in our own State of California, where nearly all varieties ever introduced have been tested, it is also the standard. When first introduced here in 187.6 old potato growers would have none of it because it was new and because it was white. You will have to hunt a long time to find red potatoes now.

The following letter will better illustrate the situation at this date than can any words of mine:

"Stockton Chamber of Commerce, Inc., Nov. 19, 1910.

Mr. Luther Burbank,

Dear Sir: Santa Rosa, Cal.

In reply to your letter of November 17th, asking for some data regarding the potato output of this vicinity, will say as Statistician for the County, my researches

* Two or more unprincipled dealers have been persistently offering these plants in the cold Northern States, well knowing that they could not prove successful. 
do not extend beyond the boundaries of San Joaquin. For San Joaquin County, the present year, 4,000,000 bushels. I think, will amply cover the production, and possibly there might be a million bushels outside of the limits of the County which are shipped by Stockton commission men or growers from points in the immediate vicinity. I have interviewed many of the shippers and find that their judgment as to the percentage of Burbanks in the output of this County ranges from 90 per cent. to nearly 99 per cent. From the best information obtained, however, I would say that 95 per cent. of the output, and especially of the shipments, are Burbank potatoes, and consequently from the reclaimed regions in San Joaquin County, immediately adjacent, there is probably an annual output of $4,750,000$ bushels of Burbank potatoes. Some Early Rose, Peerless and a few other varieties are grown early in the season, but they do not figure largely in the market except for a few weeks in the early summer.

J. M. EDDY, Sec'y.

"Stockton Chamber of Commerce, Stockton, California."

The "BURBANK" CHERRY brought in the eastern States at the wholesale public auction sales in 1908, fifteen dollars per ten pound box, and seven dollars and fifty cents per ten pound box later in carload lots, and in 1909 sold again in Philadelphia at the fabulous price of thirty-one dollars per box of ten pounds. Just three dollars and ten cents per pound wholesale.

The WICKSON PLUM, though first introduced as lately as 1894, is now grown in California, Australia, New Zealand, South America and Africa more extensively than any other plum introduced since that date, and is acknowledged to be the best shipping plum known. Nothing as large and of such fine quality had ever before been seen. By a vote of the nurserymen and growers of California last year (1909), it was placed at the head of the list as the most popular of all plums.

The PINEAPPLE QUINCE, introduced in 1899, is coming into prominence. It is acknowledged by those who have grown it to be superior to all known quinces in its unequaled quality, a revolution and a revelation in that heretofore neglected fruit. The VAN DEMAN also is largely grown and recommended as a remarkably productive variety.

The PHENOMENAL BERRY, introduced in 1893, is to-day the favorite berry on the Pacific Coast, and the person who could supply the demand for plants of the PHENOMENAL, last season has not yet been found.

The HIMALAYA BERRY , which originated on my grounds fifteen years ago, is "not like other berries," for it will and does bear more than four times more weight of fruit per plant than any other berry. Six to eight tons per acre on young fields is a fair crop, but as the plants get older they become almost trees, sometimes producing one or two hundred feet or more of branches each season and berries in proportion. The HIMALAYA is a most delicious berry, unsurpassed in quality, and the best keeper and shipper. At the Mashington U. S. Experiment Station a test was made

"I look to great practical results from Burbank's work among plants."-Thomas A. Edison. 
with all the blackberries grown at the station, the object being to discover what berry would keep the longest in good condition: my HIMALAYA kept in good condition fourteen days under this test-in other words, fully twice as long as any other berry. So much surprise was caused by this test that it was repeated with exactly the same results. Is it surprising that it is now known as the most profitable shipping berry?*

The TARRYTOWN CANNA was awarded a Gold Medal at the PanAmerican Exposition as the best and freest blooming canna then in existence. It is to-day a standard and acknowledged to be the freest flowering canna so far produced.

The BURBANK ROSE received a Gold Medal at the St. Louis Exposition as the best bedding rose. This and the SANTA ROSA are hardy throughout most of the northern States; both are very beautiful, flowering freely in warm climates every day in the year, and in cold climates excel all but two or three others in this respect.

The SANTA ROSA PLUM received a Gold Medal at the Lewis and Clark Exposition, with special mention for its great size and beauty. Its value as a shipping plum is now very well known.

The OPULENT PEACH is known by growers as the best peach in quality ever produced. It thrives over a large part of the United States.

The FRAGRANCE CALLA is the most abundant bloomer of all callas and the first and only fragrant one.

The SLGAR PRUNE is the most vigorous and productive prune known, carrying also the highest per cent. of sugar. Now especially valued for its superior shipping and selling qualities.

The GIANT PRUNE may here be mentioned for canning, and the well known AMERICA, COMBINATION, GOLD, SHIRO, CLIMAX, BARTLE'T'T, APPLE, SLLTAN and other plums. PRIMUS berry, the first recorded fixed species produced by man. The ROYAL, PARADOX, and S.ANTA ROSA walnuts, and numerous plumcots, stoneless plums, prunes, quinces, chestnuts, roses, poppies, lilies; tomatoes, opuntias; gladiolus, daisies, amaryllis, tigridias, and more than one hundred other valuable new plants, fruits and flowers, some of these not yet generally well known, but rapidly coming into the people's hands through the agency of the great seed and nursery establishments of the world, every one of which has proved better than those known before in some new quality, in some soils and climates. All do not thrive everywhere. Please name one good fruit or nut that does.

* Many spurious and seedling plants have been sold as the true Himalaya and Phenomenal by umprincipled dealers. 
Some interesting facts which have not perhaps attracted the attention of fruit growers: Within the past twenty years one hundred and twenty new plums have been introduced by various growers, dealers, and nurserymen, in the United States. Among these one hundred and twenty are twentyfour of my own production, as follows:

$\begin{array}{lllll}\text { Abundance } & \text { Doris } & \text { October } & \text { Splendor } & \text { Shiro } \\ \text { Burbank } & \text { Satsuma } & \text { Wickson } & \text { Giant } & \text { Formosa } \\ \text { Gold } & \text { First } & \text { America } & \text { Sugar } & \text { Santa Rosa } \\ \text { Delaware } & \text { Apple } & \text { Chalco } & \text { Sultan } & \text { Gaviota } \\ \text { Hale } & \text { Combination } & \text { Climax } & \text { Bartlett } & \end{array}$

The last three quite lately.

All of these twenty-four have proved successful with growers, dealers and consumers, and are quite generally catalogued at the present time. Take the catalogue of any well-known up-to-date nursery establishment, for instance, Brown Bros. \& Co., Rochester, N. Y.; the Storrs \& Harrison Co., Painesville, Ohio; George C. Roeding, Fresno, Calif., or almost any other prominent nurseryman in the United States, or D. Hay \& Son of New Zealand; John M. Rutland, of Anstralia; Senor Salvador Isquierdo, of South America; H. F. V. Pickstone \& Bros., of Africa, or any well-known foreign firm anywhere, and note the varieties listed as standards. Have the twentyfour mentioned been generally so listed? What has become of the other ninety-six new varieties which have been introduced by all other parties? The facts are these:

Nearly ninety-five per cent. of the new plums introduced since 1890, now catalogued as standards, originated on my own farms, although nearly four times as many new varieties have been introduced by other dealers. Most of the introductions of others are not now generally even listed. Then if you should again happen to ask

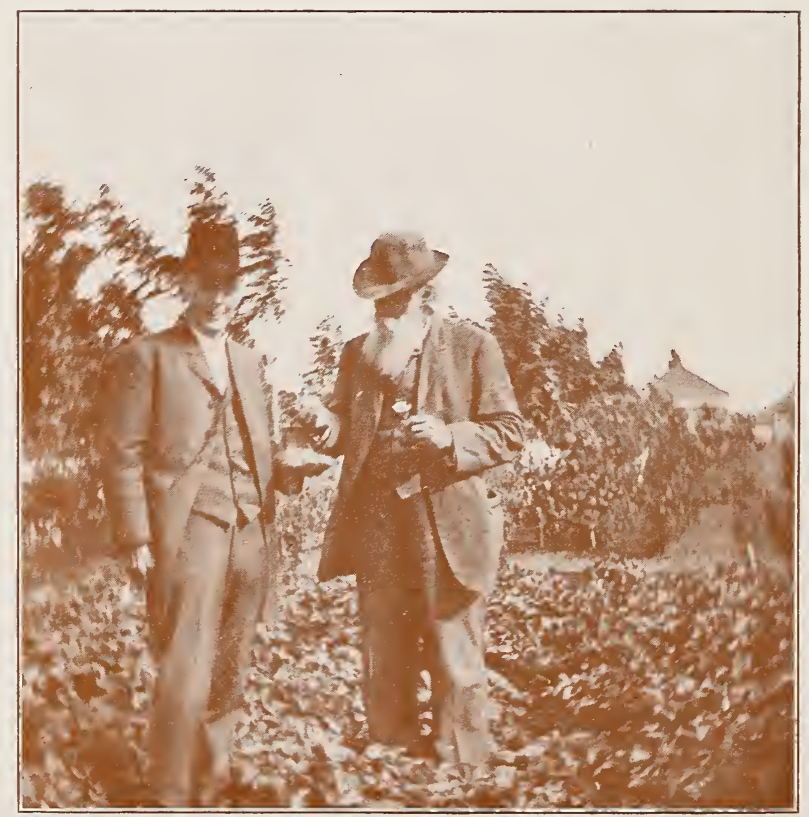

The Poet John Burroughs Likes Patagonia Strawberries.-See Page 15. 


\section{"How to Judge Novelties" (I Reply) "Look to Their Source"}

Forty-nine of the ninety-six new plums introduced by others are like the above, mostly of the Japanese type or their hybrids. The Orient, Red June, Ogon, Gonzales and Normand are sometimes still generally catalogued. How often do you see the others of this same type mentioned? They are as follows:

\begin{tabular}{|c|c|c|c|c|}
\hline Kerr & Hon-smomo & Yone-sumomo & Kel-răba & Excelsior \\
\hline Waugh & Hattankio & L Lutts & Berkmans & Wasse Botaniko \\
\hline Babcock & L Preserver & $\angle$ Red May & Ragland & L Maru \\
\hline Berger & Sagetsuma & Nagate & Engre & $\angle$ Yosebe \\
\hline Chase & Wassu & L. Yellow Nagate & er Earliest of All & 1 Gonzales \\
\hline Yeddo & L Six Weeks & Marietta & Strawberry & Orient \\
\hline Douglas & White Kelsey & Terrell & White Japan & $\sim$ Red June \\
\hline Furujiva & Williard & Goose-O & Watson & Ogon \\
\hline Holland & Yates & Kel-balan & - Sumomo & Normand \\
\hline Georgeson & Yone-momo & Kel-myro & $\checkmark$ Nona & \\
\hline
\end{tabular}

The other forty-seven which have been introduced by other parties are of various parentage, mostly Prunus Americana and Prunus domestica. Where are the bulk of these also now catalogued as standards, and who grows them?

All or one hundred per cent. of my own introductions are quite generally now catalogued by nurserymen and widely planted by growers, and at least fifteen of them are grown by the carload for shipping, by the most critical, intelligent and extensive growers of several continents, while less than twelve per cent. of all others have survived the tests of growers, dealers and consumers. I have not the least desire to make adverse comparisons with the producers or introducers of the various new plums, for whom I have the deepest sympathy and admiration; yet, owing to the false and malicious statements of the editor of a certain New York City agricultural paper, feel impelled to state the facts as above, otherwise, they would perhaps never have been investigated.

\section{HOW TO JUDGE NOVELTIES-LOOK TO THEIR SOURCE}

The old standard "Tragedy" Prune is too well known to all California fruit growers, shippers and eastern dealers to need description. Its large size, extreme earliness, beauty, quality and ability to stand the long transcontinental trip have made it very popular, and yet the tree generally fails to produce a good crop at least half the time, and in many localities is a flat failure all the time.

Its several good qualities induced me to cross it with the Sugar Prune. 
The Sugar Prune, though a month earlier, fully four times as productive and more than twice the size of the French Prune, has been often condemned -one of its worst supposed faults being that it produced too much fruit! To-day the tide is rapidly turning in its favor as the growers are realizing its value for drying and its unequaled value for shipping. Eastern retail dealers in fancy fruits like it and write that it is the "best of all sellers," and some of the wholesale firms have written to growers, "Grow all of Burbank's Sugar Prune you can; too many of them cannot be grown for the Eastern market."

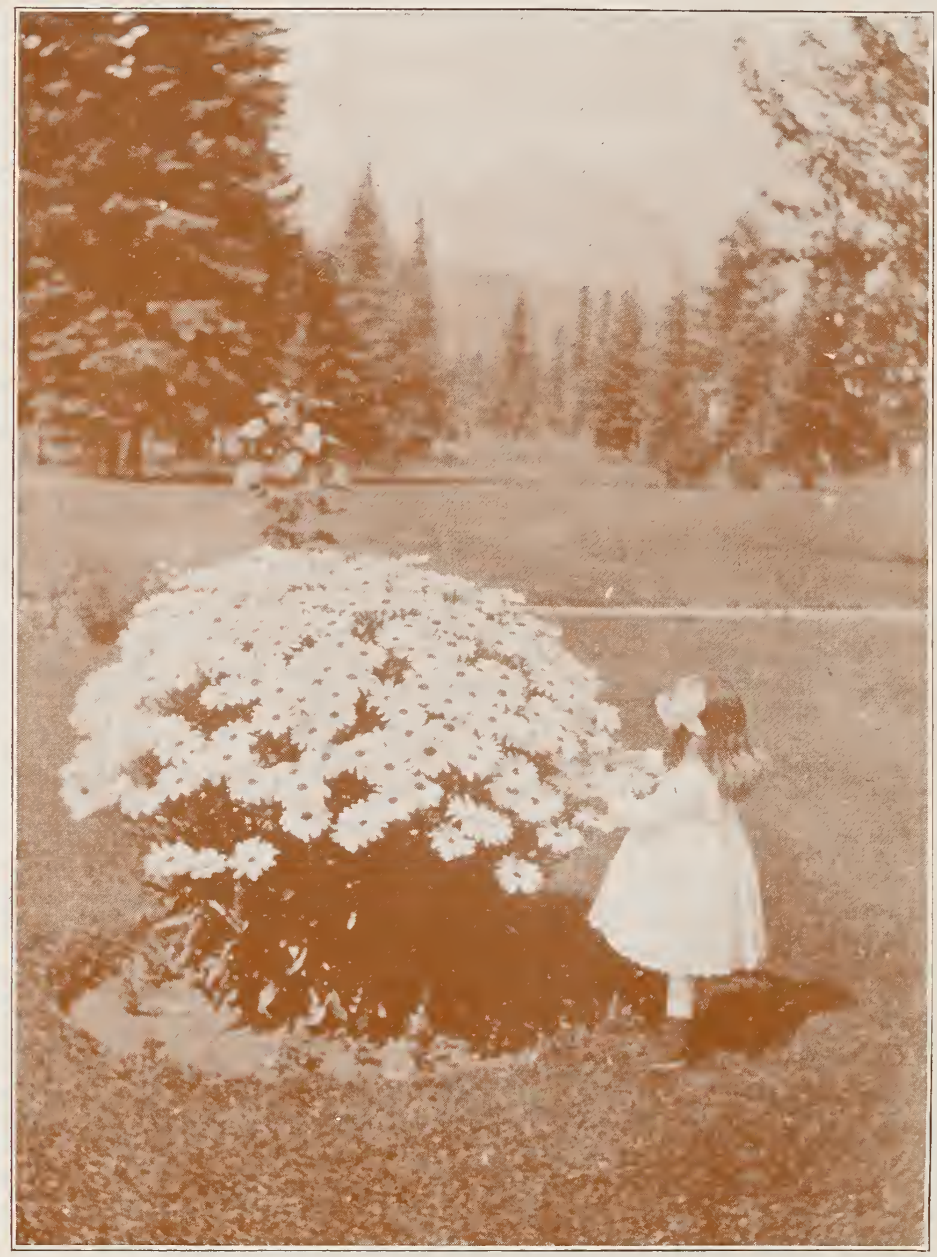

The Shasta Daisy-a Burbank Creation.

"A thousand years hence this flower (Shasta Daisy) or some of its descendants will smile in the gardens of the earth and softly speak its maker's name. Ages to come and long years after an enraged and overcrowded people have swept to the winds the idols of this generation, the Shasta Daisy will bloom on and speak of the tender, manly soul who coaxed it into being."-H. S. Garfield, M. D., in Pendleton (Oregon) Tribune. 


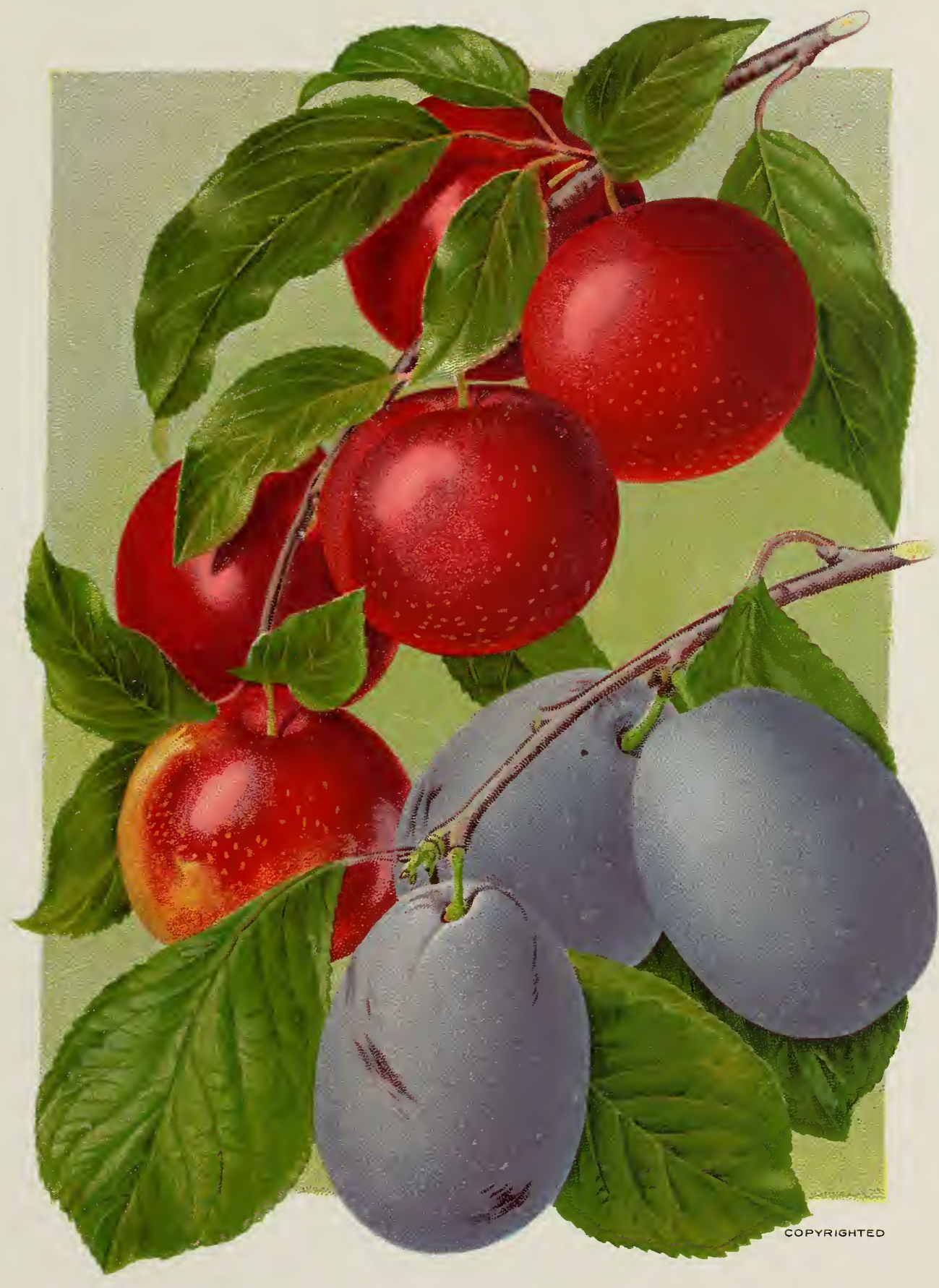

(5lom,

NEW HYBRID PLUM.

Standard.

NEW SWEET Prune.

PRODUCED BY LUTHER BURBANK. 



\section{A New Prune---The Standard}

Years ago I had made the combination of the Tragedy and the Sugar Prune and now have at last (in my opinion and the opinion of a number of the best known growers) the best prune ever produced. The trees are enormous and never-failing bearers, and good, healthy growers. WTell grown fruits measure four and a half inches around one way by nearly six inches the long way. Skin purple with a heary blue bloom; flesh amber or honey yellow, fine grained, juicy yet firmer than most other drying prunes, rery sweet and a perfect freestone.

This is without doubt the best combination drying and shipping prune ever grown; ripens September 1st and has been kept fully a month in good condition in a basket in an ordinary living-room during our warm Fall weather, and can be shipped when dead ripe with success to any part of the United States. And the final test as a prune is that when dippeci ds usual the result is a big quickly dried prune of better quality than any ever before known. I have no other and know of no other prune which compares with this in its wonderful combination of good qualities.

"It has been tried in a commercial way now, for two years, and its possibilities as a high-grade prune have been established beyond a question of a doubt."

\section{University of California, College of Agriculture \\ Agr. Experiment Station Berkeley, Calif.}

Examination of Tragedy X Sugar Prune (The "Standard") sample sent by Luther Burbank, Santa Rosa, California.

Description by Prof. E. J. Wickson:-Freestone, Pit small, 5/8" x 5/8". Flesh yellowish, melting, finc grained; very juicy and sweet. Skin dark blue-sub-color dark red, medium texture.

\section{ANALYSIS}

Arerage

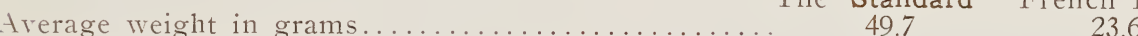

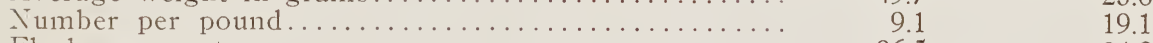

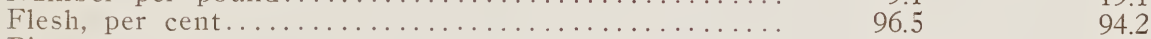

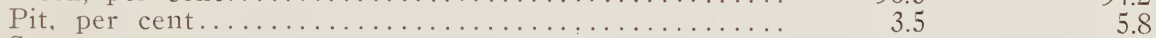

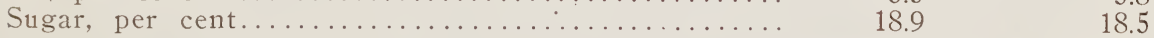

(Signed) G. E. COLBY,

Prof. Chemistry. point.

By analysis it will be noticed that it excels the French Prune in every

\section{SELECTED WOOD FOR GRAFTING.}

Per foot, \$2.00. Ten feet and over, \$1.50 per foot. (Good firm wood and good measure.)

Yearling trees, each $\$ 5.00$. Ten or over, $\$ 4.00$ each.

For those who have orchards it is generally far better to use grafting 
wood to change unprofitable peach, almond or plum trees (on all of which the "Standard" thrives); by this means fruit is produced the second season and samples often the first, and much valuable wood may be produced for the next season's nursery or orchard grafting or sale; many thousand acres of heretofore unprofitable orchards are now producing abundantly of the very choicest and most salable fruits (and shipped East by the carload) from grafting wood of new varieties which have originated on my experiment farms in the past.

"Sample of your grand new prune 'Standard' received to-day. 'Beautiful!' say all to whom I have shown it.

"Perfect in shape and color, as well as all that could be desired in size, it is rightly named 'Standard.'

"Will the wood be for sale this fall? And if so, where? I want some of the first issued to the public.

"Am sending you samples of cured 'Opulent,' we like them better than any other cured or fresh peach.

\section{“J. T. G., Morgan Hill, Cal., Sept. 6, 1910."}

"The best prune when cooked that I ever tasted."-Judge S. F. L., San Jose, Cal.

"Morgan Hill, Cal., Sept. 6, 1910.

"The 'Standard' prune is a wonderful fruit; its perfect shape, deep black color, fine flavor and richness are all that could be desired in a fresh prune, and am sure it will cure nicely. If I like it as well when cured as I do your 'Sugar,' I'll call it a better prune, on account of the pit, which is smaller and smoother, not having the sharp edge (which is about the only fault I have to find with the 'Sugar' prune), and also on account of its wonderful keeping qualities. Regarding the 'Sugar' prune, am pleased to be able to write I like it better every year. The trees are as shapely to-day as they were after the first crop. The fruit is larger, blacker, and richer in flavor each succeeding year. I regret the fact that I did not know enough to graft my 'cot trees to 'Sugar' the same time I grafted my French prune trees to it. If the 'Sugar' prune $20 / 30$ 's and $30 / 40$ 's were sold on its merits under its own name, instead of its identity being lost when the packer gets it, am confident it would soon be the favorite in the market.

J. T. G."

"I have delayed acknowledging receipt of the samples of the new prunes (the "Standard') which you kindly sent me, as I desired to taste them at their best, and when they arrived they were not quite ripe. I tested them at various stages, and after about ten days from the date of receiving them, they were in best condition. Certainly they are choice to eat when ripe in their fresh state; and I can readily understand they must make a most delicious prune when dried.

"J. L. N., Menlo Park, Cal., Sept. 10, 1909."

Five days later I sent to Mr. N. half a dozen of the dried "Standards," he replied as follows:

Sept. 15, 1909.

"This prune (the 'Standard') is truly delicious. I have never eaten anything more delicious in my life."-J. L. N. 
May 2, 1910.

"Several years ago I had one-half of my French prune orchard grafted to your 'Sugar' prune and am now sorry that the whole place was not regrafted to them. The trees are beauties and have never failed to produce a full crop. The fruit is always early, large, perfect, and brings the highest price of all, being used by the packers for 'facing." "-H. B., near Santa Rosa, Cal.

Sept. 16, 1910.

"Am pleased to learn 'The Standard' will be for sale next winter. It dries rapidly, and when cured looks beautiful. All who have seen it admire its size and color. I believe it is the best yet."-J. T. C., Morgan Hill, Cal.

"Vacaville, Cal., Sept. 5, 1910.

"The two samples of long keeping prune, the Standard, received, for which accept my sincere thanks. You certainly have produced a valuable new fruit, and I hope you will realize its full value; it will be an acquisition to the fruit industry of the State. I have shown them to several growers and all express a desire to obtain them when you are ready to dispose of them. I would like to see you realize all there is in it and will do all in my power to assist you. "Yours truly,

R. E. B., Vacaville, Cal."

"Vacaville, Cal., July 1, 1910.

"Yours received, also the new plum and cherry. I am very much pleased with the plum. I think it is one of the best plums you have ever propagated, and for this early district would be a great money maker. Will you have it for sale this coming season? The cherry is very fine also. Thanking you very kindly for sending me the samples, I am,

Yours truly,

H. A. B.

"P. S.-I am shipping over 500 crates per day of Wickson, Sugar Prunes and Splendors, all of your creation, to all Eastern cities. You have done more for the fruit men than all the world combined, and I for one appreciate your efforts and great success."

"In Santa Rosa I found another hero worthy of the name and of his fame, Luther Burbank. We spent a happy hour with him in his house and he gave me two of his books with loving words on the fly-leaf. It was a great day for us both, my wife and me. She has made an idol of him for years and truly he is worthy of it, for he is not only a genius, he is a great philanthropist whose work will redound to the everlasting honor of all mankind. California can be proud with cause of such a citizen."-Jacob A. Riis.

Alexandria, Egypt, Jan. 19, 1909.

If I wrote to you, dear sir, in former times about the possibility to cultivate your thornless Opuntia in those barren countries, I, after a long experience and a lot of traveling, am now fully convinced of the necessity to go on and to give to the poor wretched Arabs a new means of life. Just now there is painful need for food for people and cattle and I have decided to spend the rest of my life in propagating your wonderful work in this part of the world. 


\section{New Hardy Plum---The Glow}

It has been five years since I have introduced a plum; meantime innumerable complicated hybrids have been grown and tested each season, and now a new plum is offered which will become another standard (not in California, perhaps, and not for shipping), the "GLOW." It is the product of a very complicated heredity including several species. Prunus maritima, the supremely hardy little "beach plum," millions of which have been raised and fruited here, combined with the selected cream of the endless number of seedlings of Prunus Americana, the best of the hardy eastern species; Prunus subcordata of the Pacific Coast and Prunus nigra, hardy as an oak.

The new tree is a medium, slender grower with light green healthy foliage and long, slender, drooping branches, which are annually loaded with beautiful fiery crimson nearly globular plums, with faint dottings of yellow. Flesh orange color, rich, delicious (almost incomparably so), partial freestone. Ripens here September 5th to 20th; good keeper, extra fine when canned. Five inches in circumference each way.

Just a few sample expressions in regard to some of these new fruits are added from experts only. I could add five-or six-hundred somewhat similar letters, but the fruits sent out from this establishment in the past should be sufficient. Many other prominent growers have seen them on my grounds, but not elsewhere. As Bailey says, "A fruit which is generally tested is already introduced." A word to the wise is sufficient.

Prices: Orders now taken for yearling trees to be delivered fall of 1911. Each, $\$ 3.50$. Ten for $\$ 20.00$. Wood for grafting, $\$ 2.00$ per foot.

"The Subcordata hybrid ("Glow") is something extraordinary. For persons who appreciate plums for their quality it seems to me it will rank as one of the best you have produced."-J. L. N., Menlo Park, Cal.

"I have your favor of July 22d, also the plums 'Delicious America' by mail. I have eaten them and I have no hesitation in saying that I have never tasted any other plum which I think equal to the 'Delicious America' in exquisite and delicate flavor. The color of the skin is also most attractive. I think it would be hard for anyone to eat as many of these plums as one would like, as the flavor is so delicate that they do not cloy on one's taste. As fine as we all considered the 'Climax,' 'Sultan,' 'Combination' and other of your earlier varieties, I certainly think they are now far surpassed by such plums as your 'Santa Rosa,' 'Found,' and many other varieties which I tasted at your place on my last trip.

"With kindest regards, I remain,

J. L. N., Menlo Park, Cal."

"I ate the Subcordata plums 'Glow' last evening, that were canned during my absence, and if you have not before had any of them cooked, I am sure you will be surprised to find how well adapted they are for preserving. I do not think any better plum for this purpose is grown. Judge L. had told me before I went East of the superior quality of this late plum for eating out of hand. It must be a plum of the greatest value."-J. L. N., Menlo Park, Cal. 
"The greatest service which can be rendered to any country is to add a useful plant to its culture."-Thomas Jefferson.

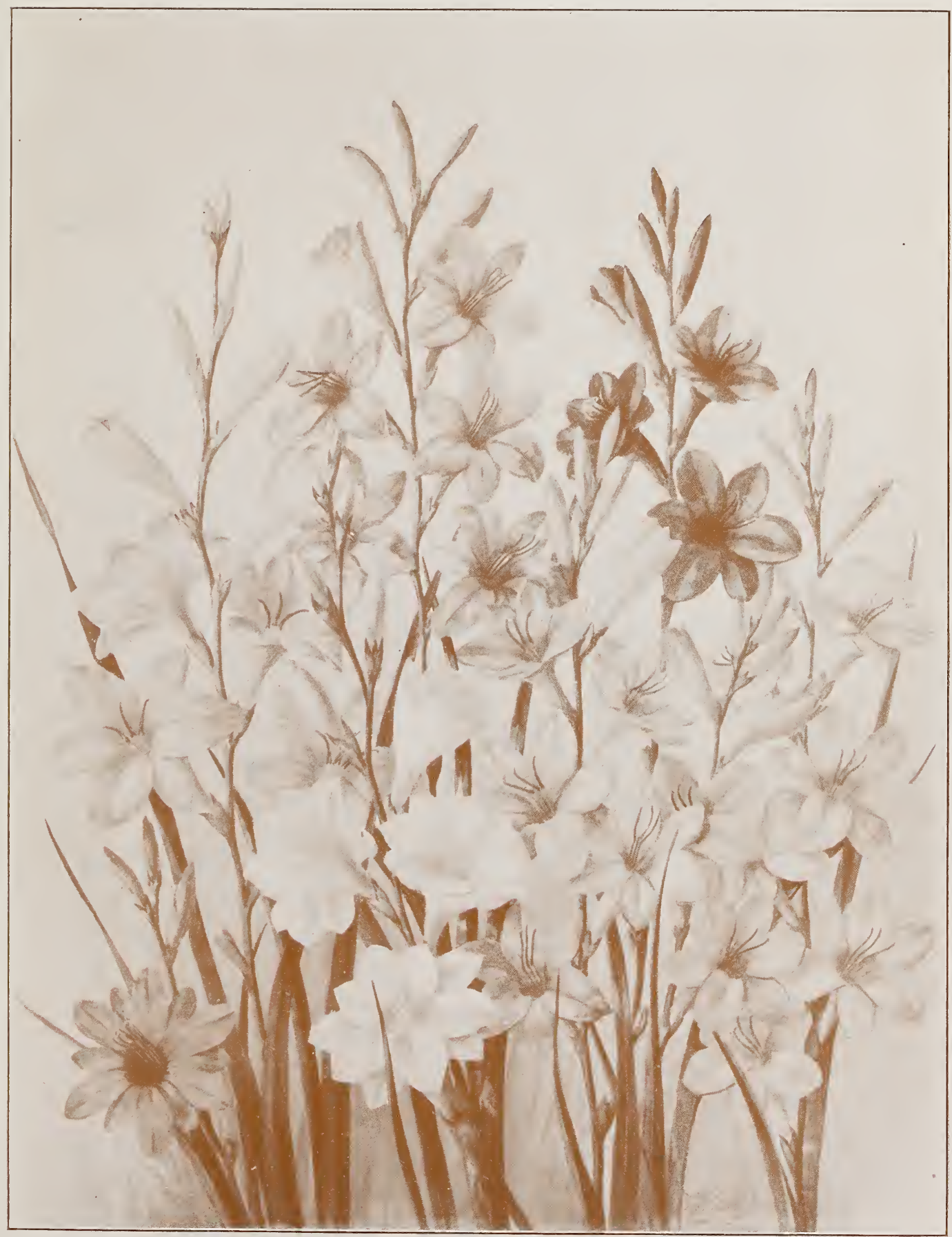

Burbank's Watsonia Hybrids. New Types, New Colors, Enormous Flowers. Double and Single. 


\section{A New Strawberry of a New Type---The Patagonia}

The strawberries are an exceedingly variable genus of plants, mostly natives of Europe, North America and the West Coast of South America. Some scientific botanists divide the genus into one hundred and thirty species, while others make only three or four species at most. Take your choice in this matter. It only indicates what all are slowly learning, that horticulture may be as accurate a science as is the classificatory botany of the schools.

The strawberries of the present time are about where the potato was forty years ago; many varieties are imperfect in blossom, others adapted only to certain soils and special conditions of culture, many are subject to various foliage diseases, sume produce one crop and then disappear, not. being able to produce an abundance of fruit and sufficient runners for renewal, others produce too many "nubbins" or imperfect berries, others toe many runners.

Several species may have contributed towards the production of the common garden strawberry, but it is generally admitted that all our best strawberries have descended wholly or in part from one of the Chilian strawberries (Fragraria Chiloensis). No known wild strawberry compares with the modern hybrids in their general combination of good qualities even with their many defects.

Some twenty-five years ago the work of improving the strawberry was commenced on my grounds; all the popular varieties of that time and also the wild strawberries of New England, Alaska, Norway and the far better ones of the California seashore and mountains were used. Many promising new ones were produced, but none which were thought sufficiently improved to replace the best then known and the work of improving the strawberry was discontinued until five years ago, when one of my Chilian collectors (from whom I have received during the past five years more than three thousand species of new wild Argentine, Chilian and Patagonian plants), sent seeds of the wild strawberries from both the lofty Cordilleran mountains between Chile and the Argentine Republic and from the Coast regions of Southern South America. Among these new wild strawberries were some with unusual qualities, which promised to be of untold value when amalgamated with the best European and American strains.

The best combination in this work with new material resulted from the crosses of the best of the new Chilian with Brandywine, Longworth's 
Prolific, Monarch, Marshall and some of our native California berries, but no striking or very unexpected results were observed until the second generation, when among the very numerous hybrid seedlings under test was found this unique berry, which was at once recognized as the grand prize which has at last been produced, after such expense, labor and care during the past twenty-five years.

\section{DESCRIPTION OF THE NEW HYBRID STRAWBERRY, “THE PATAGONIA."}

Of the twenty standard varieties of strawberries now growing on my home places the "Patagonia" commences to ripen first and continues to bear the longest.

Well grown plants are about one foot in height and twelve to eighteen inches across. The leaves are large and unusually thick and firm, with a thin silky down, and are never injured by sunburn, where other varieties are either seriously browned or wholly destroyed.

The berries grow on stiff branching stalks, which, while generally holding the berries free from the ground, yet do not expose them to the hot sun, so that in warm, dry weather the berries keep here in best condition a week or more on the vines. The berries are uniformly large, single berries sometimes weighing an ounce each at the beginning of the season, decreasing somewhat in size during the heat of mid-summer, but are even larger in the fall if the runners have been removed; fine scarlet color with a handsome pale yellow flesh. The seeds are so very small as to be almost imperceptible.

The berry though firm and a remarkably good keeper is of most exquisite quality, melting in the mouth with a sweet pineapple, strawberry and cream like flavor, and can be freely eaten by those who cannot eat the common acid strawberries now grown.

The calyx is extraordinarily large. This keeps the berries apart, giving an air space, making them keep much longer than ordinary berries and adding a peculiar fresh beauty when offered in boxes or baskets.

But above all, this new strawberry is a home berry. Easy to raise, producing great quantities of large, firm, sweet, delicious, pineapple-flavored berries without the usual care necessary to produce good strawberries. It is the first of a new race which has come to make strawberry growers rejoice.

Everyone who has seen the "Patagonia" has been surprised and de- 
lighted with the vigor and surprising productiveness of the plants, the size, beauty, exquisitely delightful flavor and aroma of this, the King of Strawberries.

This new strawberry is confidently expected to take at once the same high place in the estimation of planters, dealers, and consumers that the Burbank potato, Burbank plum, Shasta daisy, Burbank and Santa Rosa roses, Giant Winter rhubarb, Phenomenal and Himalaya berries and our numerous other productions have taken, becoming world-wide standards of excellence -in other words, of the "Burbank Quality."

Everybody knows John Burroughs, the poet and writer; he says, "Tronderful pineapple flavor": "the most delicious strawberry that I ever tasted."

George C. Roeding proprietor of the great Fancher Creek Nurseries, says, "The vigor of the plant is most remarkable, the fruit most delicious."

Dr. George H. Shull, of the Cold Spring Harbor Experiment Station, Long Island, New York, says, "Never have I seen such a vigorous, healthy lot of strawberry plants; the berries are delicious. Never tasted any fruit of any kind to equal them."

Henry W. Kruckeberg, editor and publisher of the Rural Californian and other horticultural magazines, says, "The best strawberry that I have ever tasted."

Dr. S. E. Chapman of Oakland, California, says, "The most delicious morsel that I have ever tasted in my life."

Hermon Brown, Curator Public Gardens, Rhodesia, Africa, says, "The most delicious strawberry I ever tasted, either cultivated or wild."

Dr. Gustav Eisen, the well-known botanist and writer on horticultural subjects, says, "Absolutely new in growth and appearance, in quality superb."

\section{PRICES :}

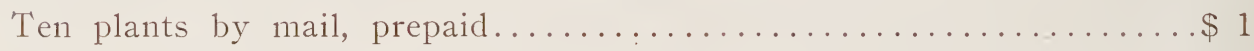

Twenty-five plants, prepaid, by mail or express............. 2

One hundred plants by express, not prepaid................ 44

One thousand plants by express or freight...............\$30

Plant now on any good soil in rows three feet apart, fifteen inches apart in the rows. For an abundance of berries, pull off the runners and give plenty of water.

LUTHER BURBANK, Santa Rosa, Cal., U. S. A. 


\section{A New Cherry---The Burbank}

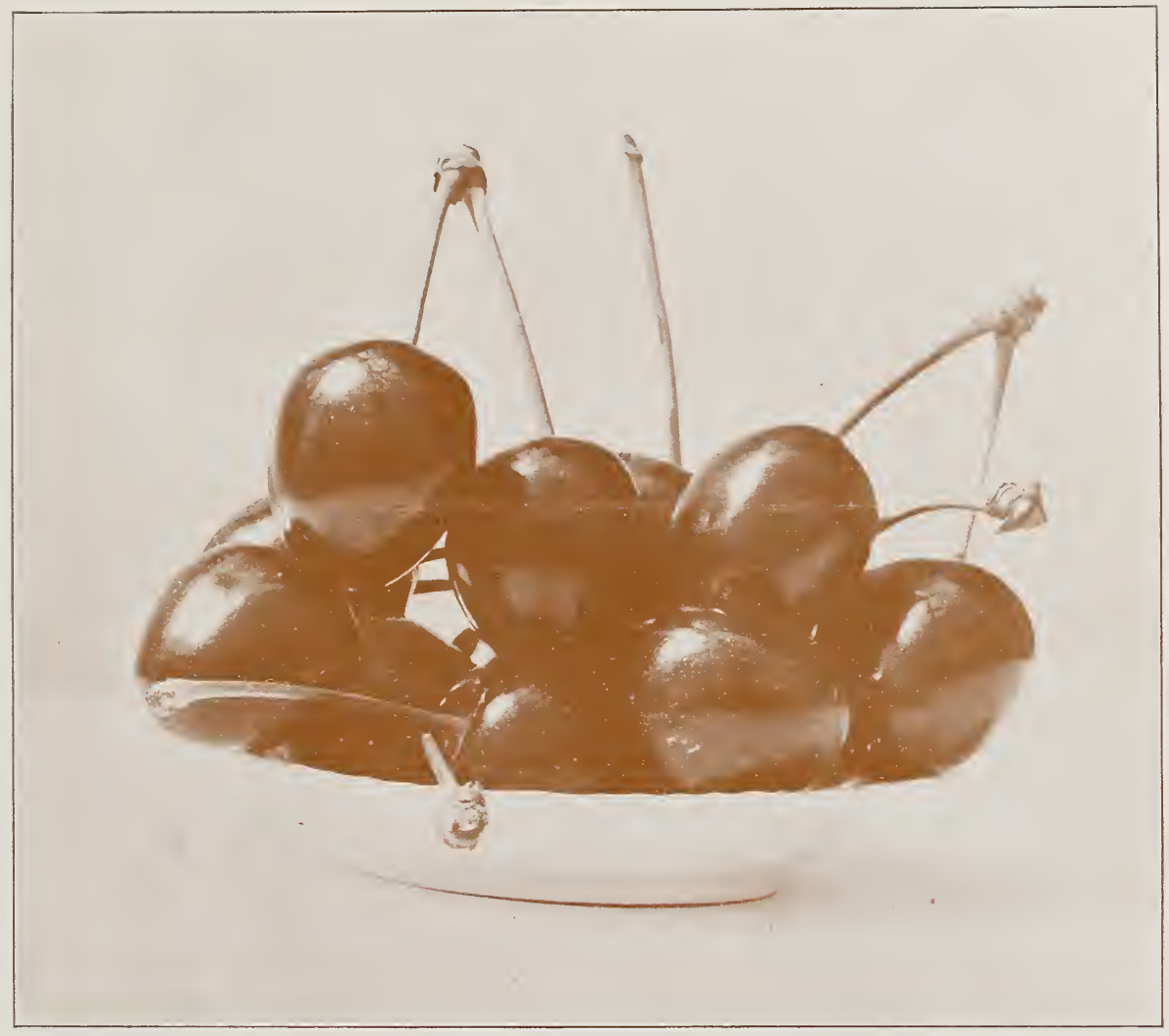

A little over one-half natural size.

The earliest of all large cherries. The largest of all early cherries, and not only the best of all early cherries, but unsurpassed by any cherry of any season.

The "Burbank" brought in the Eastern States at the wholesale public auction sales in 1908, fifteen dollars per ten pound box, and seven dollars and fifty cents per ten pound box later in carload lots, and in 1909 sold again in Philadelphia at the fabulous price of Thirty-one Dollars per box of ten pounds. Just three dollars and ten cents per pound wholesale.

The trees are models in form, vigor and never-failing productiveness.

The foliage, which is of unusual size, is so placed that the fruit is fully protected from birds and cracking by late Spring rains.

The fruit is extremely large for an early cherry, attractive deep crimson color, and of superior quality.

The "Burbank" is THE early cherry.

Only a few one-year-old trees for sale this season, $\$ 1$ each; ten for $\$ 7$. 
"Some qualities Nature carefully fixes and transmits, but some, and those the finer, she exhales with the breath of the individual as too costly to perpetuate. But I notice also that they may become fixed and permanent in any stock, by painting and repainting them on every individual, until at last Nature adopts them and bakes them into her porcelain."-Emerson.

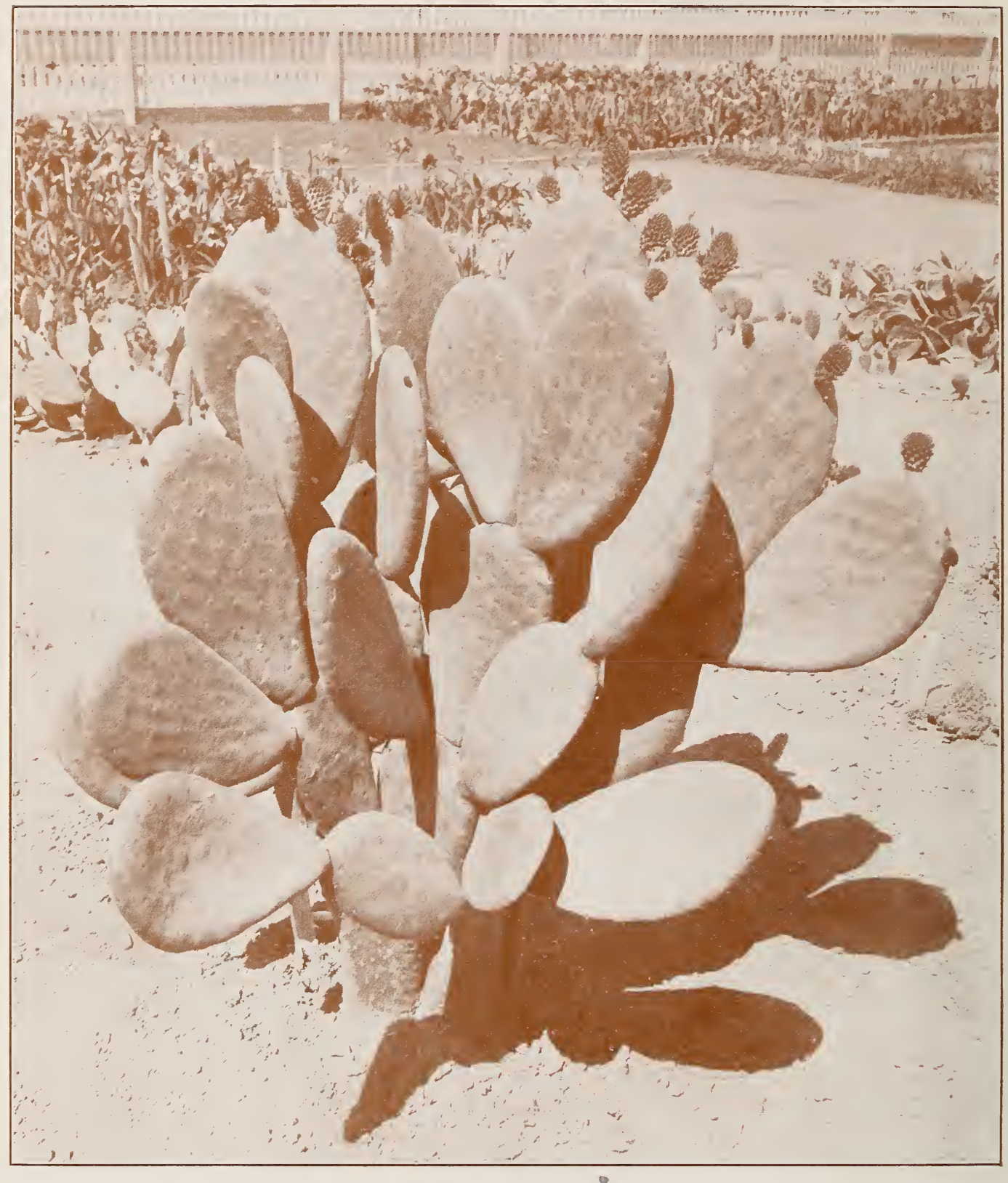

One of Burbank's Absolutely Spineless Cactus Plants, Two Years Old from Cutting. 


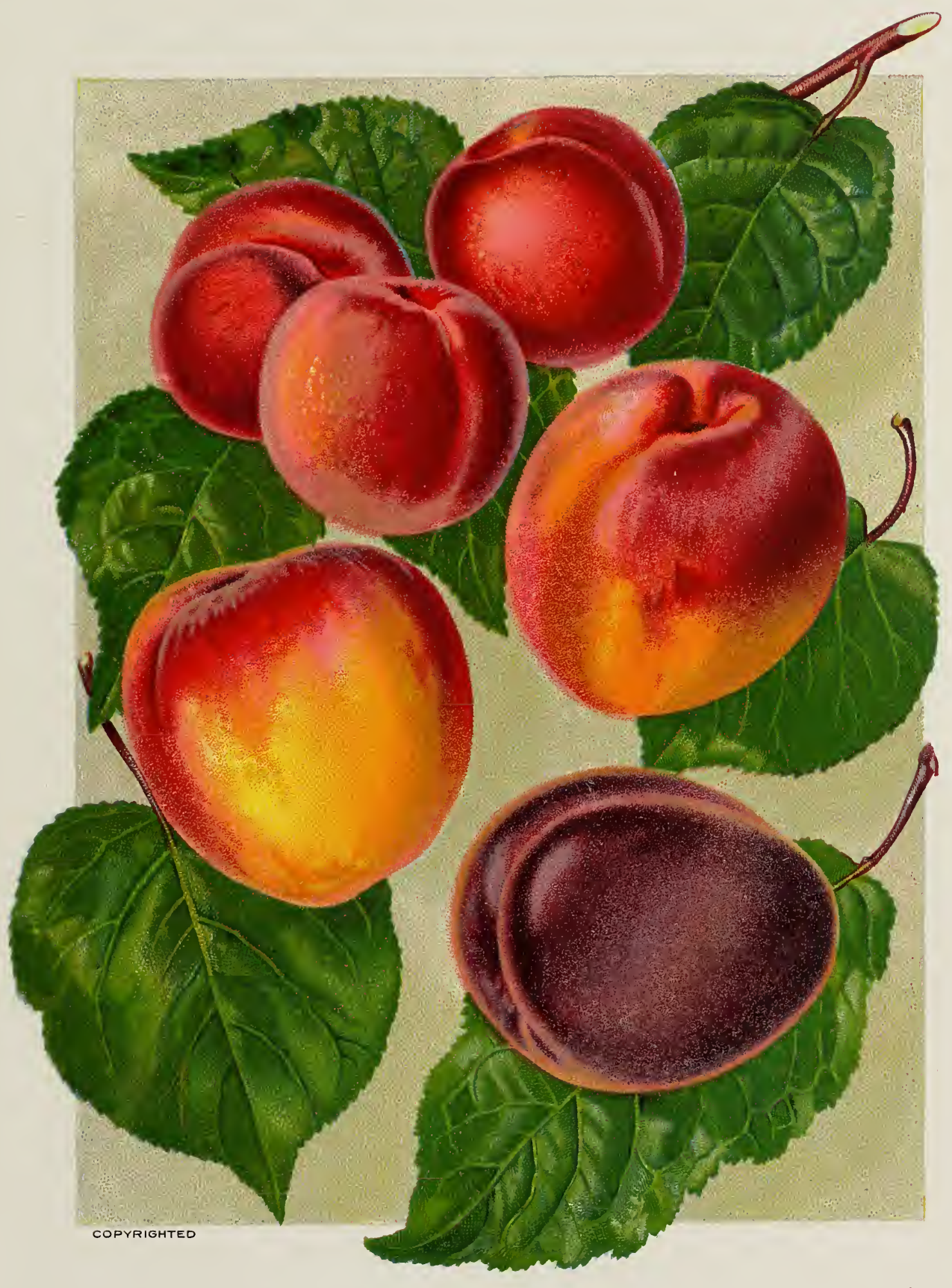

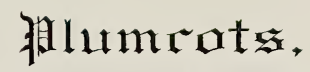

Plate i. Samples of a distinct new species of fruit produced by luther Burbank. 



\section{The Spineless Cactus}

For hundreds, probably thousands of years, the great, rapid growing, desert thorny cactus (Opuntias and others) have furnished food for stock and fruit for man, especially in Southern Europe, Northern Africa and Mexico, where the fruit, though rather seedy and difficult or almost dangerous to handle, is very highly prized, more so perhaps than any other fruit except the orange and banana.

The whole plant furnishes nutritious food in abundance, yet great pain and often death was the penalty for using them.

Fourteen years ago the first scientific experiments for their improvement were instituted on my farms. Eight years later when these costly experiments were crowned with success beyond the imagination of anybody, the United States Department of Agriculture became interested and some ten thousand dollars or more was authorized for a search for "thornless" ones.

All countries where they grew were literally scoured with the hope of finding one of great agricultural and horticultural value like those already produced on my farms-the result was a failure.

There is and never was a spineless cactus in existence except those produced by my own efforts, which will produce at the rate of 180,230 pounds of forage and 198,637 pounds of large, beautiful, delicious fruit per acre the third year from rooted cuttings, as my new ones have done here.

Beware of the so-called "spineless" cactus sent out by the Department of Agriculture; they are not spineless and are not safe to handle or to feed to stock. The fruit is insignificant, seedy, and poor when compared with the improved varieties, not up to the "Burbank Standard," though claimed to be "just as good as Burbank's."

New cactus catalogue next June, which is the proper time for planting.

No cactus of agricultural or horticultural value will grow except in semitropical climates.

"His (Burbank's) occasional catalogues of 'New Creations' are models of concise and dispassionate writing." * * *

"He turns out more new fruits than words, which isn't altogether a bad thing to do for a man whose work and joy it is to do precisely that."-Independent, N. Y.

"Of all the men who have practiced the fine arts, Mr. Burbank has the keenest eye and the best memory. Therefore, he is the greatest artist, and in the years to come will be remembered and regarded as the greatest of artists."-President David Starr Jordan, Stanford University.

"The judgment as to what will likely be good and what bad is the very core of plant-breeding. In this judgment Burbank excels. Not to many men is given this gift of prophecy. Burbank calls it intuition. He cannot explain it any more than another man can explain why he is a good judge of character in human beings. Long experience and close observation have directed and crystallized this faculty of his, until it is probably as unerring as such faculties can be."-Prof. L. H. Bailey, Cornell University. 
"By honoring Luther Burbank, of Santa Rosa, the California Academy of Sciences this week honored itself and the State (in awarding him the first Semi-Centennial Great Gold Medal). Wherever civilized man tills the soil, the name of Burbank is known as that of a benefactor of his kind. He is easily the greatest Californian of to-day, if service of the race is to be the test. He has improved nearly every vegetable that finds its way to the market; he has created new fruits and given new value to the old ones; and he has added beauty, size, and fragrance to nearly every flower in the garden.

"He has led a strenuous life of the better sort. He has been great without engaging in war, and without wrecking other businesses to inciease his own. California does not yet appreciate him, but time will come when the memory of the man who made the pitless prune, the giant plum, the Shasta daisy and the best potato ever raised will be held far dearer than that of any merely successful politician or military leader."-Star, San Francisco, Cal.

"March 7 has been made a legal holiday and Arbor Day in the State of California, in honor of Luther Burbank, who was born on that day. The honor is a well deserved one, for Burbank will certainly take rank, not only as a man of wonderful attainments, but as a man whose life work has been of great and undying benefit to the human race. The growing custom of honoring such men by holiday observances rather than by the erection of monuments of pulseless marble or bronze is to be commended as a modern departure from a custom of pagan origin."-Prescott, Ariz., Courier, March $15,1909$.

"I have a sample of your Phenomenal berry the past season and I must say 1t is a gem; people came for miles to see it in fruiting and everyone who saw it pronounced it a grand creation."-H. T. M., Grangeville, Idaho.

"The Climax plum does exceedingly well in this locality and is becoming more and more in demand."-B. Bros., Vacaville, California. The great shipping point of deciduous fruits.

Bell Flower, Los Angeles C.o., California, December 5, 1910.

"The cherry trees and strawberry plants were packed better than any that I have ever before receivd. Thank you for promptness and for extras."-R. G.

June 24, 1910.

"I have been trying many kinds of potatoes here in this hot climate, but none do as well as the California 'Burbank,' originated by yourself."-E. S. K., Hacienda de Rio Claro, Papantla, Estado de Vera Cruz, Mex.

Nov. 10, 1910.

"Have been growing your Crimson Winter Rhubarb for five years. I sold $\$ 765.00$ worth of stems from one acre in one season, in spite of a good deal of bad luck."-W. A. L., Mgr. L. Bros. Produce Co., Gardena, Cal.

"I consider that Mr. Burbank's work has been of very great value to hybridizers. I know that from my personal acquaintance with Mr. Burbank I received more points of value than from all other hybridizers put together, and as I have sold from the new varieties of carnations, which I have produced, over $\$ 100,000$ worth of plants and flowers since Mr. Burbank advised me, I feel that any effort to injure or discredit Mr. Burbank will be taken by successful hybridizers as not justifiable. Mr. Burbank has done an immense amount of practical work at a great personal sacrifice and I do not think that he deserves to be hammered because the newspapers have been improvident in the way of writing sensational articles about his great work." - C. W. W., Queens, L. I., Aug. 19, 1910. 


\section{The Crime of the Sunberry (Wonderberry)}

"I was reading the other day of the experience of a famous and honored scientist who had, after years of patient effort, produced a new food berry which meant a new, cheap, useful and delightful food for the whole race. You all know the man, for his wonders in the creation and propagation of new and beautiful forms of flower, plant and fruit life have made his name a household word. But about the new food berry.

"When the discovery was given to the world, it and its discoverer were instantly attacked, and although the assailants had,never seen the new fruit and knew nothing about it, they set up a great hue and cry that it was worthless, and even poisonous.

"From this starting point other horticulturists took up the cry against him and the new fruit, and the most malicious and untruthful reports about it became current all over the world. Never in the history of horticulture was such a well-organized and so persistent a crusade against a man ever launched, and all based absolutely upon false assertions. Not one of the envious and jealous had any personal knowledge of the new food berry whatsoever, but seeds were procured early and started under glass. By April some small seedling plants, three or four inches high, had set and partly ripened a few fruits. As might be expected under those conditions, the berries were small and tasteless. Here then was proof positive that the thing was worthless, and all its enemies and rivals were happy. They met to felicitate one another, to pass resolutions, and to write press notices condemning the new fruit, and kept at it until the middle of summer, inducing tens of thousands of people who had the plants to pull them up and throw them away, thus helping along the crusade against it.

"By the end of July plants, grown under proper conditions in the open ground, all over the country began to mature fruit, and a shower of favorable reports set in. At this time the head of the New York Botanical Garden made a report that was favorable, after a careful study of the plant growing in the grounds of the Botanical Garden, by himself and associate professors.

"Before the middle of August 'the crime' of the new food berry was fully exposed and the motive generally understood. Then came the wailing of those who had been misled into destroying their plants.

"By September it was fully vindicated in all parts of the country and its creator was deluged with letters praising it.

"The discoverer had not been injured, but great damage and annoyance had been done to innocent people-how many, the world will never know-more than 350,000 people had planted seed of the new food berry."-Editorial, "The Woman's Magazine," February, 1910.

"One way to measure your success is by the earnestness with which your competitors lie about you."

"The flowers and fruits of California are less wonderful than the flowers and fruits which Mr. Burbank has made. He is a unique great genius. In the hope of seeing what he has done is the greatest reason why I should come to America. He has carried on the breeding and selection of plants to fixed ends. Such a knowledge of Nature and such ability to handle plant life would only be possible to an innately high genius. He is a man of whom California and the world should be proud. $\mathrm{He}$ is already in California highly treasured but not in the right way. He is a man to be honored and he should also be generously helped, but in whatever help is given to him he should remain undisturbed. The time will come when he will be as well known and as highly cherished in California as he is now among the scientific men of Europe."-Dr. Hugo De Vries, Amsterdam, Holland.

Aug. 30, 1910.

"It is amazing what opposition one has in experimenting and the ignorance there is to contend with; therefore, my sympathy and admiration of the great work you have done is very hearty indeed, and should I be of any use in Europe I shall esteem it a privilege."-E. Mc.D., Bristol, England. 


\section{How to Judge Novelties---Look to Their Source}

The people are the final judges in all matters, whether of new fruits and flowers, or of any other production of the human mind and soul. A new bean, melon, radish, or cucumber may be fully tested and its value known in a few months. Several years are required to test the tree fruits, so that growers, dealers and consumers may fully know their real value.

The greatest inconvenience and injustice I have met is not misunderstanding, prejudice, envy, jealousy, ignorance or ingratitude, but that purchasers are so often deceived by various unscrupulous dealers who, taking advantage of the name "Burbank" hoist on the public green carnations, hardy bananas, U. S. Government thorny cactus for Burbank Thornless ones, blue roses, seedless watermelons, cigars, real estate, magazine articles, false statements of having been in my employ, and a thousand other things; and by outrageous misrepresentations or the change or addition of a word or two from the correct descriptions, deceiving purchasers even when a genuine product of real value may happen to be offered.

"With the labor and assiduous attention removed that the Carnegie Institute demanded of Burbank during the life of its appropriations he is enjoying a much wider freedom, which has stimulated new endeavor along plant breeding lines." Henry W. Kruckeberg, Editor "Rural Californian” and other rural publications.

Yes! After having been under "capture" for the avowed purpose of "the benefit of science" for five years by the Carnegie Institute of Washington, five years of care, leanness, hampering restrictions and unprofitable conditions, and having dictated to and corrected for their botanists several thousand pages, it is a most gracious relief to return to a life free from the red tape of institutional restrictions, with its accompaniment of envy and jealousy, to a life of active freedom. My whole business has been reorganized during the past twelve months and more good fruits and flowers may be expected from time to time as of yore.

January, 1911.

LUTHER BURBANK,

Santa Rosa, Cal.

"I was very glad to hear that you got clear from the capitalist power and influence, as no man with a gift and guided by intuition could succeed under such influence."G. L., San Jose, Cal.

"Luther Burbank is so interesting a subject to the general public that his personal friends have had to take active measures to save him from his admirers. Not only do people flood him with questions by mail, but a large proportion of the visitors to the Pacific Coast do not think their duty done without stopping off at Santa Rosa to have a chat with the originator of the spineless cactus. As a result. Mr. Burbank is not 'at home' to the public, and his approaches are guarded rather more effectually, if anything, than those to the President of the United States."-Washington (D. C.) Herald. 


\section{H. S. Garfield, M. D}

Oregon.

'There is nothing in floral creation to excel the 'Alaska' Shasta Daisy in profusion, and no marguerite in existence can hold up its head unabashed in 'Alaska's' dazzling presence.

"The claims made for this daisy were so large that I would have discounted them, coming from most any other source. I now behold the facts and look upon the claims as modest. I am astounded at the plant. The big, white blooms completely blanket the bed and people passing in carriages and automobiles pause and rave over them. I cut 700 blooms yesterday from three plants without stripping them. The stems are long; wiry, stiff and just right to carry the big flower gracefully. The blooming season is heaviest in July, but continues until November. People heretofore indifferent to all single daisies and marguerites bow down at 'Alaska's' snowy shrine.

"The wave undulating from the spot where you have cast this pebble into Nature's placid pool will radiate for centuries after the memories of the achievements of our Alexander or a Napoleon have passed into eternal shadow. This flower, or some of its progeny, will bloom on earth ages after this era has been forgotten. Nations will rise and fall; civilizations will wax and wane; religions die, be born again and be either stifled or nourished in the lap of science, but through it all the Shasta Daisy will smile upward in confidence toward the great, mysterious beyond into which its synthetical creator has been merged and go firmly and hopefully on in its manifest destiny to propagate its species forever.

"H. S. GARFIELD."

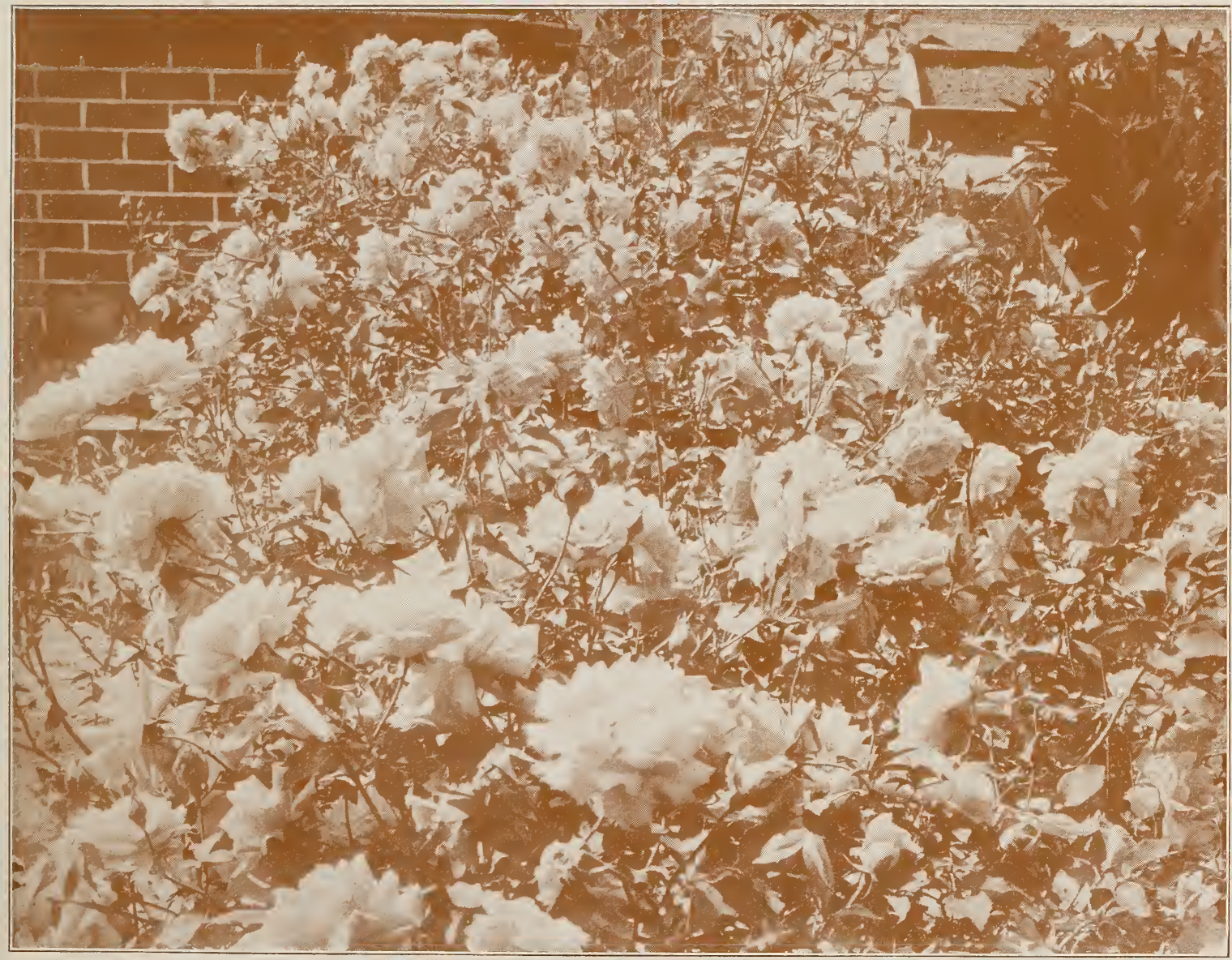

The Everblooming "Santa Rosa” Rose. 
On inside back cover will be found a photograph of one of my "Santa Rosa" walnut trees. As far as known this tree produces more nuts, which sell at higher prices (with never a failure of crops) than any other walnut tree on earth.

Mr. Luther Burbank,

Campbell, Cal., Oct. 3, 1910.

Santa Rosa, Cal.

Dear Mr. Burbank:-

Your favor of recent date at hand inquiring about record of the "Santa Rosa" walnut tree.

We kept no record of the first few crops. The record since is as follows:

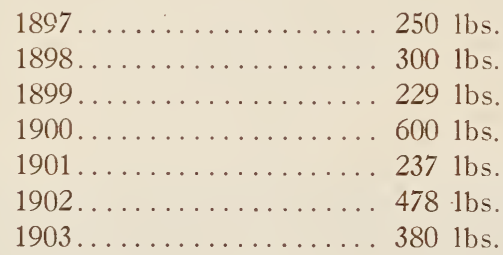

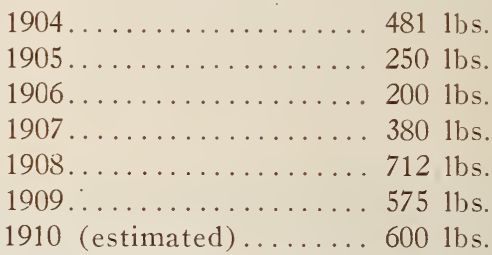

These nuts have always sold from two to five cents more per pound than the socalled "No. 1's" from Southern California.

With kindest regards, I am,

Yours very truly,

GEORGE C. PAYNE.

Judge's Chambers County Court, Juvenile Court,

Mr. Luther Burbank,

Ben B. Lindsey, Judge.

Santa Rosa, Cal.

My dear Mr. Burbank:-

I have been so much interested in your work with other plants that I felt like shouting for joy when I found that you were equally interested in the human plant, where there is as much opportunity for progress as in the life of those plants you have so wonderfully developed. Seven years in the children's court, and much study in all the large cities in this country of the trials and tribulations of childhood and the problem of crime so directly related thereto, has tremendously impressed me with the necessity for the education of the masses along these lines, and I welcome a thou. sand times to the literature on the subject your little volume, which I have been reading with the greatest interest, and which seems to me to come nearer pointing the right way than anything that has come under my observation.

I do want to congratulate you upon this valuable addition you have made to the great work of child-saving, or rather man-saving and man-making.

Sincerely yours,

BEN B. LINDSEY, Denver, Colo.

"I have seen mean, envious things in the press since Carnegie help had been given-but, of course, you will not mind them. Led by your genius, you will plod doggedly, industriously on your flowery. fruitful, Godful way with the sincere admiration of every lover of Nature and mankind.

"With all good wishes and warm regard, I am every faithfully yours, 


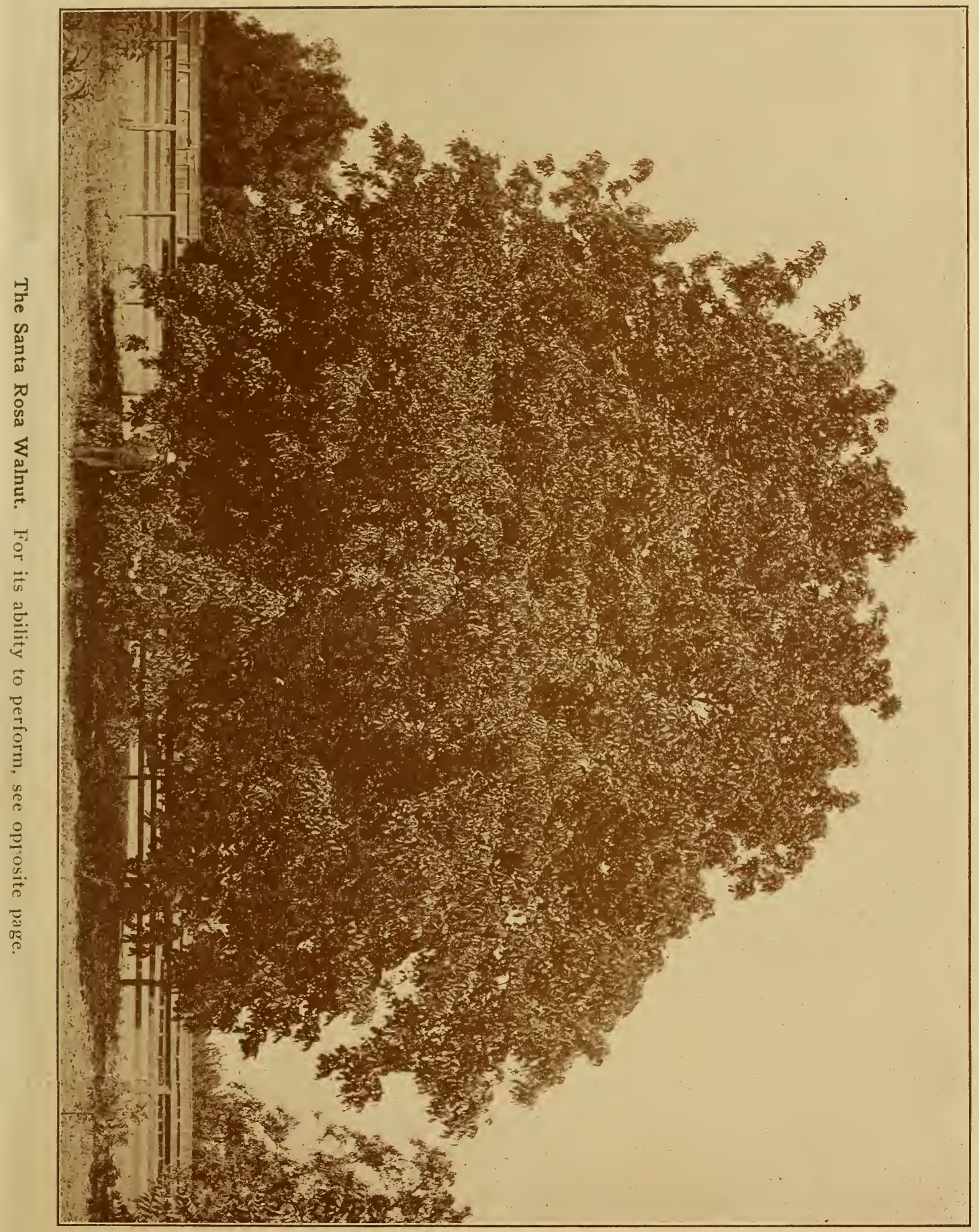




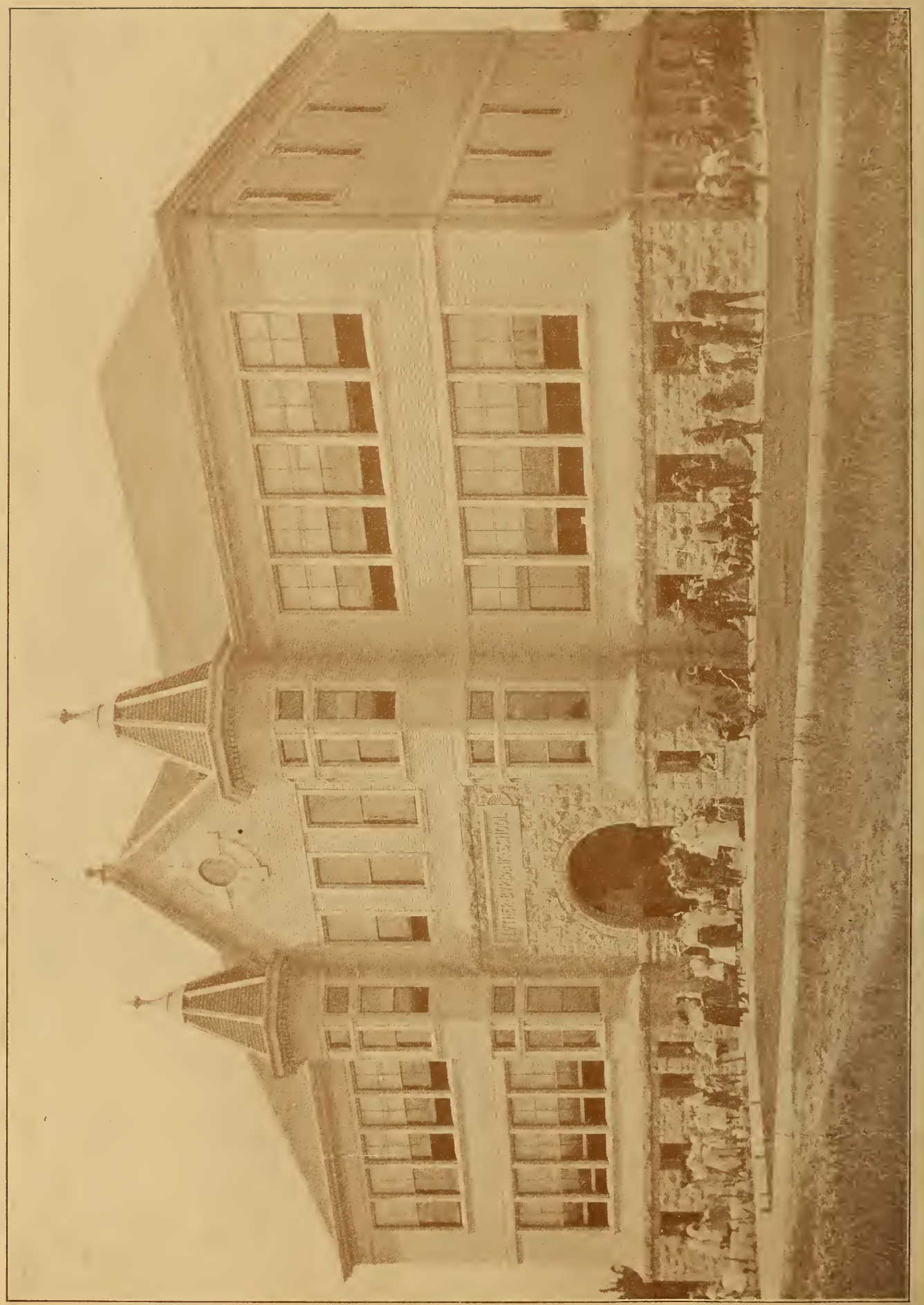

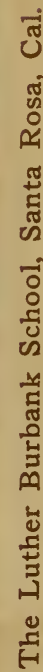

